\title{
O Svetome pismu u Origenovoj misli
}

\author{
IVICA RAGUŽ* \\ • https://doi.org/10.31823/d.27.3.1 • \\ UDK: 27-23-9 • Izvorni znanstveni rad \\ Primljeno: 24. siječnja 2019. • Prihvaćeno: 9. rujna 2019.
}

* Prof. dr. sc. Ivica Raguž, Katolički bogoslovni fakultet u Đakovu Sveučilišta J. J. Strossmayera u Osijeku, P. Preradovića 17, p. p. 54, 31400 Đakovo, Hrvatska, ivica.raguz@os.t-com.hr

Sažetak: Članak analizira Origenovo shvaćanje Svetoga pisma. U prvom dijelu analiziraju se uvjeti i pretpostavke za razumijevanje Pisma u Origenovoj misli. Veliku ulogu ima sv. Pavao i njegova interpretacija Staroga zavjeta. Također se upozorava na osobni život vjernika (duhovnost, obraćenje) koji je također jedan od temeljnih uvjeta za cjelovitije tumačenje Pisma. Drugi dio članka promišlja Origenovo ophođenje prema Starom zavjetu, osobito u kontekstu hereze gnoze. Treći dio predstavlja Origena kao egzegeta i propovjednika. Origenova egzegeza uvijek je bila motivirana $i$ usmjerena prema navještaju Božje riječi u liturgiji. Progovara se o prednostima takve egzegeze, kao i o ograničenostima isključivo znanstvene, akademske egzegeze. Takoder se donose i njegova, $i$ danas za Crkvu aktualna, promišljanja o nekim svojstvima, ali i opasnostima propovjednika.

Ključne riječi: Origen, Sveto pismo, Stari zavjet, egzegeza, gnoza, propovjednik, homilija.

U ovom članku nije nam namjera ulaziti u opsežne analize Origenove teološke i egzegetske misli. Ovdje se želimo samo zadržati na jednoj temi, a to je Origenovo razumijevanje Svetoga pisma i njegova uloga u teologiji i u životu Crkve. Naime Origenova je teologija u pravom smislu riječi biblijska teologija, a Origen je biblijski teolog par excellence, ako on, kako sam često navodi te riječi u svojim tekstovima, o Pismu misli »dan i noć« (Ps 1,2$).{ }^{1} \mathrm{Na}$ temelju krajnje predana razmatranja i proučavanja Svetoga pisma, dakako, u skladu s naukom Crkve (alegorija), Origen predstavlja

${ }^{1}$ Usp. Hom. Lev., 2, 4. (Homélies sur le Lévitique, Introduction, traduction et notes par M. Borret, Paris, 1981.) 
cjelokupnu kršćansku vjeru: otkriva u čemu se sastoji specifičan kršćanski moral, danas bismo rekli kršćanski svjetonazor (tropologija), a potom i kršćanska mistika, duboko i intimno zajedništvo Boga i čovjeka (anagogija). Jer, razmatrajući nad Božjom riječju, smatra Origen, vjernik se može i treba istinski sjediniti s Isusom Kristom. ${ }^{2}$ U tom smislu mogli bismo reći da u Origenovoj teologiji susrećemo izvornu $\gg k r-$ šćansku misao «, ukoliko njegova misao izvire iz izvorišta izvorno »kršćanskoga «, iz samoga Pisma, odnosno iz Božjih riječi koje sa svoje strane izviru iz izvorišta triju božanskih osoba, tih triju »zdenaca « Božjega života. Ili pak, kako to kaže Origen, sva teološka znanost, sva misao treba proći kroz »tijesak Pisma « kako bi postala plodna, tj. kršćanska. ${ }^{3}$ To znači da, baveći se Origenovim razumijevanjem Svetoga pisma, ulazimo u samo središte njegove cjelokupne teološke misli: »Proučavajući Sveto pismo u Origenovoj misli i životu dolazimo u srce njegova djela. $\ll^{4}$

Ovo ćemo izlaganje podijeliti u tri dijela. U prvom dijelu progovorili bismo najprije o Origenovu temeljnom pristupu Svetomu pismu, odnosno o pretpostavkama i uvjetima za razumijevanje Pisma. Drugi dio bit će posvećen njegovu razumijevanju Staroga zavjeta. A u trećem dijelu predstavit ćemo Origena kao teologa propovjednika. Pokazat ćemo kakav bi propovjednik trebao biti prema Origenu.

\section{Pretpostavke i uvjeti za razumijevanje Pisma}

\subsection{Pavao}

Premda se u Origena može primijetiti utjecaj grčke filozofske misli za razumijevanje Pisma, što je uostalom vidljivo kod svih ranokršćanskih mislilaca, ipak je on svoju teološku metodu razvio iz pozornoga čitanja Svetoga pisma. Tomu u prilog svjedoči i činjenica da se Origen obilno nadahnjuje židovskom egzegezom (Fi$\operatorname{lon}^{5}$ ), koju često spominje u svojim tekstovima kao konzultiranu literaturu, ali i druženjem s rabinima u Cezareji.

No Origenovo razumijevanje Svetoga pisma povrh svega proizlazi iz vjere $u$ Isusa Krista, odnosno iz osobne vjere u Isusa Krista. Naime Origen je ponajprije vjernik ${ }^{6}$,

\footnotetext{
${ }^{2}$ Usp. Hom. Gen., 10, 5. (Die Homilien zum Buch Genesis, eingeleitet und übersetzt von P. Habermahl, Berlin - Boston - Basel - Wien, 2011.) O Origenovoj mistici, koja je biblijska mistika, vidi: W. VÖLKER, Das Vollkommenheitsideal des Origenes, Tübingen, 1931.

${ }^{3}$ Usp. Hom. Ps. 36, 1, 2. (Homélies sur les Psaumes 36 à 38, Introduction, traduction et notes par H. Crouzel, L. Brésard, Paris, 1995.)

${ }^{4}$ J. DANIÉLOU, Origene. Il genio del Cristianesimo, Rim, 1991., 165.

${ }^{5}$ Vidi: J. DANIÉLOU, Filone d'Alessandria, Rim, 1991., 137-159.

${ }^{6} \mathrm{Na}$ tome s pravom inzistira Charles Kannengiesser u svojem članku: A Century in Quest of Origen's Spirituality, u: L. F. PIZZOLATO, M. RIZZI (ur.), Origene maestro spirituale, Milano, 2001., 15-19.
} 
predani vjernik koji vjeruje u Isusa Krista. Zanimljivo je primijetiti da gotovo nema nijednoga teksta iz njegovih homilija i komentara gdje ne bismo susreli nježne i intimne izraze poput $\gg$ moj Isus «. To je važno imati na umu jer se bez toga ne može razumjeti Origenova teološka misao, kao ni njegovo tumačenje Svetoga pisma. Jer je u svojoj srži Origenov spoznajno-duhovni napor usmjeren traganju i pronalaženju $\gg$ njegova Isusa «, koji se svugdje skriva pod velom slova Pisma.

Origenov Isus jest Isus Crkve: Bog i čovjek. Riječ je, konkretno, o tome da se u Isusu Kristu, kao Bogu i čovjeku, susreće vidljivo i nevidljivo, tjelesno i božansko, odnosno tjelesno se u Isusu Kristu, za Origena, može razumjeti kao »slovo « unutar kojega je skriveno njegovo božanstvo. U tom smislu sama vjera u Isusa Krista donosi kršćanima osjećaj za »duhovni smisao«, a to znači za duhovno razotkrivanje onoga što Krist jest u svojem »slovu «, ljudskom, tjelesnom, a to je Bog. ${ }^{7}$ Stoga se Origen posve razumljivo poziva na Kristove riječi da je Bog duh (Iv 4, 24). Time se želi reći da se duhovno, božansko, može razumjeti jedino na duhovan način. Origenu su također važne i sljedeće misli iz Ivanova evanđelja: »Duh je onaj koji oživljuje, tijelo ne koristi ništa. Riječi koje sam vam govorio duh su i život su.« (Iv 6, 63) Kristove su riječi »duh«, zato one zahtijevaju duhovno, produhovljeno tumačenje Svetoga pisma. ${ }^{8}$

Dakle, budući da je Isus Krist autor cijeloga Svetoga pisma, ono se, prema našem autoru, može i treba tumačiti jedino u vjeri u Isusa Krista. Budući da je Isus Krist Bog, da on sjedi na nebesima, Sv. pismo zahtijeva za svoje razumijevanje da njegovi tumači, egzegeti, budu Kristovi, a to znači, duhovni, nebeski, a ne zemaljski koji slijede samo »slovo koje ubija « $(2$ Kor 3, 6). Naime, prema aleksandrijskom teologu, oni koji su tjelesni, koji tvrde da »istina ne može nigdje stajati osim na zemlji ${ }^{9}$, ti ne mogu razumjeti duhovni smisao Pisma. »Stajanje na zemlji « označava kod Origena sve one koji tvrde da je istina ovozemaljska, da ona ne dolazi od zajedništva s nebeskim Kristom koji sjedi s desna na nebu (Kol 3, 1-2). ${ }^{10}$ Zato Origen često poziva slušatelje da se uzdignu iznad $\gg$ zemaljskih misli do razumske kontemplacije, do pronicavosti srca ${ }^{11}$. Stoga vjernik, teolog, egzeget mora živjeti »duhovno «, molitveno i liturgijski, kako je to sam Origen činio. Dakle nužan je za

\footnotetext{
${ }^{7}$ Usp. Hom. Lev., $1,1$.

${ }^{8}$ Usp. isto, $4,1$.

${ }^{9}$ Hom. Gen., 13, 3.

${ }^{10}$ Usp. Hom. Num, 23, 1. (Homélies sur les nombres, Introduction et traduction A. Méhat, Paris, 1951.) Isto, 28, 3 .

${ }^{11}$ Isto, 3, 3. Također Hom. Ps. 36, 3, 3.
} 
razumijevanje Pisma snažan duhovni život, stalna molitva ${ }^{12}$. Jer postoji opasnost za vjernike, teologe, da ostanu u dubokom snu, zatvorenih očiju, nesposobni shvatiti duhovno u Pismu. ${ }^{13} \mathrm{Ne}$ ulazeći u detalje $\mathrm{i}^{14}$, upravo to kristološko obzorje ključ je za razumijevanje Origenova tumačenja Svetoga pisma.

Konkretno pak, Origen se uvijek iznova u svojem tumačenju Svetoga pisma najviše poziva na sv. Pavla. Stoga se može reći da je njegova egzegeza u svojoj biti pavlovska egzgeza kojom se on koristi za tumačenje bilo Staroga bilo Novoga zavjeta. Pavao dokazuje da je alegorijska metoda, koju primjerice Celzo niječe kršćanima i optužuje ih da čine nasilje nad Svetim pismom, sasvim opravdana i utemeljena kod samoga sv. Pavla. ${ }^{15}$ Naime temeljni tekst koji često navodi Origen jest Pavlov tekst iz Druge poslanice Korinćanima: »On nas osposobi za poslužitelje novoga Saveza, ne slova, nego Duha; jer slovo ubija, a Duh oživljuje. Pa ako je smrtonosna služba, slovima uklesana u kamenju, bila tako slavna da sinovi Izraelovi nisu mogli pogledati u lice Mojsijevo zbog prolazne slave lica njegova, koliko li će slavnija biti služba Duha. Jer ako je služba osude bila slavna, mnogo je slavnija služba pravednosti. I zbilja, nije ni bilo proslavljeno ono što je u toj mjeri proslavljeno, ako se usporedi s uzvišenijom slavom. Jer ako je ono prolazno bilo slavno, mnogo je slavnije ovo što ostaje. Imajući dakle takvo pouzdanje, nastupamo sa svom otvorenošću, a ne kao Mojsije, koji je stavljao prijevjes na lice da sinovi Izraelovi ne vide svršetak prolaznoga. Ali otvrdnu im pamet. Doista, do dana današnjega zastire taj prijevjes čitanje Staroga zavjeta: nije im otkriveno da je u Kristu prestao. Naprotiv, kad god se čita Mojsije, do danas prijevjes zastire srce njihovo. Ali kad se Izrael obrati Gospodinu, skinut će se prijevjes. Gospodin je Duh, a gdje je Duh Gospodnji, ondje je sloboda. A svi mi, koji otkrivenim licem odrazujemo slavu Gospodnju, po Duhu se Gospodnjem preobražavamo u istu sliku - iz slave u slavu.« (2 Kor 3, 6-17)

Oslanjajući se na taj Pavlov tekst, Origen polazi od toga da je Sveto pismo, odnosno Stari zavjet, skriven, da je Isus Krist razotkrio u cijelosti smisao Staroga zavjeta jer je on sam autor toga istoga Pisma. Origen često navodi riječi iz Ivanova evanđelja: »Uistinu, kad biste vjerovali Mojsiju, i meni biste vjerovali: ta o meni je on pisao. Ali ako njegovim pismima ne vjerujete, kako da mojim riječima vjerujete? « (Iv 5,

12 »Molitva je najvažnija za razumijevanje božanskih spisa.« Origen, Pismo Grguru: LG 4/SC 148, 192.

${ }^{13}$ Usp. Hom. Gen., 7, 6. Hom. Ex., 4, 5.

${ }^{14}$ Više o tome: P. W. MARTENS, Origen and Scripture. The Contours of the Exegetical Llife, New York, 2012., 156-160.

${ }^{15}$ Usp. Contra Celsum, 4, 49. (Gegen Celsus I-V, eingeleitet und kommentiert von M. Fiedrowicz, übersetzt von C. Barthold, Freiburg - Basel - Wien, 2011. - 2012.) 4, 87; 5, 60; 6, 70. 
46-47) ${ }^{16}$ Isus Krist skinuo je sada $\gg$ prijevjes $\ll$ s Pisma i dao mu potpuni i istinski smisao. Stoga se, za Aleksandrinca, Stari zavjet ne može razumjeti bez Krista, koji jedini može skinuti prijevjes sa Staroga zavjeta. ${ }^{17} \mathrm{Za}$ kršćane, osobito za ezgegete, to znači da je temeljni uvjet za potpunije razumijevanje Svetoga pisma Isusa Krist, odnosno odnos s Isusom Kristom. Budući da je Isus Krist autor Pisma, odnosno Duh Sveti ${ }^{18}$, tko se više približuje Kristu, postaje jedno s njim te je na taj način osposobljen sve dublje otkrivati »dublji smisao « Pisma, Staroga i Novoga zavjeta. Ili, kako također ističe Origen, što se više zbližavamo s Kristom, što više »otkrivenim licem odrazujemo slavu Gospodnju «, što se više »po Duhu Gospodnjem preobražavamo $u$ istu sliku - iz slave u slavu ${ }^{19}$ ili pak što više sjedimo do njegovih nogu i slušamo njegovu riječ, dobivamo više od njegova svjetla te možemo snažnije i dublje prodirati u smisao Svetoga pisma. ${ }^{20} \mathrm{U}$ tom smislu za Origena, što ćemo kasnije produbiti, Pismo zaista $\gg$ raste čitanjem Pisma $\ll\left(\right.$ Grgur Veliki $\left.{ }^{21}\right)$, ali raste jedino većom vjerom u Isusa Krista.

Na tragu rečenoga, drugi Pavlov tekst, koji se također učestalo pojavljuje u Origenovim djelima, jest sljedeći: »To i navješćujemo, ne naučenim riječima čovječje mudrosti, nego naukom Duha izlažući duhovno duhovnima.« (1 Kor 2, 13) To znači da duhovni smisao Svetoga pisma mogu shvatiti duhovni, tj. oni koji su potpunije predani Isusu Kristu. Ali također u Origenovoj misli uvijek se naglašava da treba $\gg$ duhovno s duhovnim uspoređivati $\ll$, duhovni smisao Pisma uvijek pronalaziti uspoređujući ga s drugim duhovnim smislima Svetoga pisma. ${ }^{22} \mathrm{Ključan} \mathrm{tekst} \mathrm{za}$ Aleksandrinca također je iz Poslanice Rimljanima: $\gg$ Zakon je, znamo, duhovan; ja sam pak tjelesan, prodan pod grijeh « $(\operatorname{Rim} 7,14)$, čime se pretpostavlja da se Stari zavjet treba kristološki, duhovno tumačiti. Naposljetku susrećemo i sljedeći tekst: »Stoga mi od sada nikoga ne poznajemo po tijelu; ako smo i poznavali po tijelu Krista, sada ga tako više ne poznajemo. $\ll(2$ Kor 5,16$)$ Origen i u tome tekstu uviđa opravdanost svoje duhovne egzegeze. ${ }^{23}$

\footnotetext{
${ }^{16}$ Usp. isto, 2, 4.

${ }^{17}$ Usp. Hom. Gen., 2, 3. Također: isto, 6, 1; 7, 1. Contra Celsum, 2, 5-6.

${ }^{18}$ Usp. Hom. Lev., $1,1$.

${ }^{19}$ Usp. Die lateinisch erhaltene Homilie über 1 Sam. 1-2, 3. (Die Homilien zum Ersten Buch Samuel, eingeleitet und übersetzt von A. Fürst, Berlin - Boston - Freiburg - Basel - Wien, 2014.)

${ }^{20}$ Usp. Hom. Gen., 1, 7.

${ }^{21}$ Hom. Ez., $1,7$.

${ }^{22}$ Usp. Hom in Lev., 5, 8. Moderna će egzegeza tu Origenovu egzegezu nazvati $\gg$ metodom paralelizama $\ll$ ( $\gg$ méthode des parallélismes $\ll)$. Vidi o toj metodi: L. SCHWIENHORST-SCHÖNBERGER, Das Hohelied der Liebe, Freiburg - Basel - Wien, 2015., 20s. Slična se metoda susreće i kod antičkih autora: »Homera treba pojašnjavati Homerom.«

${ }^{23}$ Usp. Hom. Ps. 36, 1, 1.
} 
Nadalje će za Origena veliku ulogu imati i Pavlov tekst iz 1 Kor 2, 14-15: »Naravan čovjek ne prima što je od Duha Božjega; njemu je to ludost i ne može spoznati jer po Duhu valja prosuđivati. Duhovan pak prosuđuje sve, a njega nitko ne prosuđuje. $\ll{ }^{24}$ Vrlo često Aleksandrinac se referira i na učenike na putu u Emaus iz Lukina evanđelja. Tako naš pisac tvrdi da će se Gospodin pojaviti »na našem putu $\ll$, kao kod učenika na putu u Emaus, ako o njemu promišljamo i razmatramo. ${ }^{25}$

Naposljetku treba spomenuti još jedan Pavlov tekst koji se provlači u Origenovim djelima: »Sve se to, kao pralik, događalo njima, a napisano je za upozorenje nama, koje su zapala posljednja vremena.« $(1$ Kor 10,11$)$ Upravo taj tekst baca svjetlo na Origenovo duhovno tumačenje Pisma. Naime Origen polazi od toga da je sve što je napisano u Pismu, od opisa povijesnih događanja pa sve do molitava, zapisano nama kao $\gg$ upozorenje $\ll$, odnosno nama za $\gg$ pouku $\ll .{ }^{26} \mathrm{U}$ tom smislu kršćani čitaju cijelo Pismo stavljajući ga $u$ »odnos prema sebi (»referamus et ad nos «). ${ }^{27}$ Upravo ta ideja Pisma kao »upozorenja «, pouke, jest ono što za našega pisca utemeljuje duhovno tumačenje Pisma. Kršćane ne zanimaju ponajprije povijesne činjenice kao takve, nego činjenice samo ako su kao »upozorenje $\ll$, » pouka « za vjernički, duhovni život. Zato je razumljivo da će Origen govoriti o Pismu kao o nekoj vrsti lijeka, terapije za dušu. ${ }^{28}$

To, dakako, ne znači da Origen ne pokazuje nikakav interes za povijest, za »historijsko « tumačenje Pisma. Naprotiv, Origen je vrstan filolog, za njega je i sama filologija izraz Božje providnosti, Božjega dara koji je Bog dao čovjeku da proučava Sveto pismo, kao što je to činio primjerice prorok Daniel. ${ }^{29}$ Međutim povijesnost nije njegov prvotni interes, njegov je interes Pismo kao Božja riječ koja čovjeku rasvjetljuje život, prekorava njegove grijehe i koja ima namjeru dovesti nas u odnos s Isusom Kristom. Dakako, to ne vrijedi za sve biblijske tekstove jer se neki jednostavno ne odnose na nas, oni donose određene povijesne i druge činjenice koje se

\footnotetext{
${ }^{24}$ Usp. Hom. Gen., 7, 4. Hom. Num., 1, 1.

${ }^{25}$ Usp. Hom. Gen., 11, 3.

${ }^{26}$ Usp. Hom. Num., $1,1$.

${ }^{27}$ Hom. Gen., 1, 3. Hom. Ex, 2, 1. (Homélies sur l'Exode, Traduction P. Fortier, introduction et notes H. de Lubac, Paris, 1947.) Literatura o toj temi kod Origena u: A. FÜRST, Einleitung, u: ORIGENES, Die Homilien zum Ersten Buch Samuel, eingeleitet und übersetzt von A. Fürst, Berlin - Boston Freiburg - Basel - Wien, 2014., 3-114.

${ }^{28}$ Usp. Die griechisch erhaltenen Jeremiashomilien, 14, 1-2. (eingeleitet, übersetzt und mit Erklärungen versehen von E. Schadel, Stuttgart, 1980.) Vidi također: P. W. MARTENS, Origen and Scripture, 193.

${ }^{29}$ Usp. Hom. Num., 18, 3, 3. Vidi o tome: P. W. MARTENS, Origen and Scripture, 77-87.
} 
ne tiču duhovnoga života. ${ }^{30}$ Drugim riječima, Biblija je napisana ponajprije čovjeku za spasenje, a ne da bi se on bavio njome kao povijesnom knjigom.

\subsection{VRelo Pisma I VRelo dUŠE}

Za istinsko razumijevanje Pisma potrebno je također i razumijevanje vlastite duše. Za Aleksandrinca Sveto pismo i čovjekova duša dvije su knjige koje se zajedno trebaju čitati i zajedno tumačiti. To znači da smo potrebiti Pisma kako bismo razumjeli sebe, ali i razumjeti Pismo možemo samo ako razumijemo sebe. To nije nikakav subjektivizam, kako je primijetio de Lubac, nego jednostavna činjenica da se Pismo ne može razumjeti ako čovjek nije dopustio da se Božja Riječ ukorijeni u njegovoj nutrini. Izvrsno to sažima de Lubac: »Pismo je znak, koji mi obično razotkriva moju dušu. No, i obrnuto ima svoju istinu. Jedno služi drugomu kao reagens. Svaki put kad sam vjeran Božjemu duhu u tumačenju Pisma, moje tumačenje dobiva određenu valjanost. Svaki put kada iskopavam svoj zdenac, koji uvijek iznova zatrpavaju neznalice, čistim istodobno i zdenac Pisma. $\ll^{31}$ Nije moguće razumjeti Pismo, kako tumači Origen, ako nam je izvor nutrine zatrpan, ako ga mi sami ili drugi zatrpavaju $\gg$ tjelesnim « tumačenjem Pisma, tumačenjem koje prlja naše izvorište. ${ }^{32}$ Mnogi zato misle $\gg$ zemaljski « i ne mogu razumjeti Sveto pismo (usp. Fil 3, 19). ${ }^{33}$

U tom smislu nemoguće je razumijevati Pismo ako iznutra nismo otkopali $\gg z d e-$ nac « svoje nutrine. ${ }^{34}$ To se otkopavanje vlastita zdenca događa po vjeri u Isusa Krista, koji je istinski autor Pisma, ili pak po Duhu Svetom koji je također nadahnuo Pismo. Dakle samo onaj koji vjeruje u Isusa Krista i koji se daje zahvatiti Duhom Svetim može pravilno razumjeti Sveto pismo. Ili opet, Origenovim mislima, ispravno tumačiti Božju riječ može samo onaj koji u sebi ima istu »vodu $\ll$, isto izvorište, zdenac koji se nalazi kao i u Pismu, odnosno u Kristu:»Kao što reče Pismo: 'Rijeke će žive vode poteći iz njegove utrobe!’ «(Iv 7, 38; 4, 4) Štoviše, može se dogoditi i sljedeće: ako riječi propovjednika ne proistječu iz toga vrela, one čak mogu biti potpuno istinite, ali nikako ne donose okrjepu vjernicima. Nedostaje im $\gg$ tankoćutnosti «, postaju teške, kako kaže Origen. ${ }^{35}$ Razlog je tomu taj što propovjednik ne izriče Pismo svojom nutrinom, odnosno njegova nutrina postaje zaprjekom za djelovanje Božje riječi u vjernicima.

\footnotetext{
${ }^{30}$ Usp. Die griechisch erhaltene Homilie über 1 Sam 28, 3-25, 2. (Die Homilien zum Ersten Buch Samuel)

${ }^{31}$ H. de LUBAC, Geist aus der Geschichte. Das Schriftverständnis des Origenes, Einsiedeln, 1968., 406s.

${ }^{32}$ Usp. Hom. Gen., 13, 2.

${ }^{33}$ Usp. isto.

${ }^{34}$ Usp. isto, 12, 5. Hom. Num., 12, 1.

${ }^{35}$ Usp. Hom. Is., 6, 5-6. (Omelie su Isaia, traduzione, introduzione e note a cura di M. I. Danieli, Roma, 1996.)
} 
S pravom zato upozorava de Lubac, tumačeći Origena, da se duhovni smisao Pisma ne može otkriti ako se ne živi duhovno, ako se ne »živi to isto otajstvo. Štoviše, događaj duhovne spoznaje podudara se s događajem obraćenja. Događaj spoznaje njegova je svijetla strana. 'Duhovno razumijevanje daruje vjerniku spasenje.' (Augustin) Božja Riječ, živa i djelotvorna Riječ, zadobiva svoje istinsko dovršenje i puninu svojega značenja jedino po preobrazbi koja nastaje u čovjeku koji ju prima. Zato je razumljiv izričaj 'prijeći na duhovni smisao', što ništa drugo ne znači nego se 'obratiti Kristu', pri čemu se to obraćenje nikada ne može shvaćati kao dovršeno. Između obraćenja Kristu i spoznaje Pisma postoji uzajamno uzročna poveznica. $\ll^{36}$ De Lubac nastavlja: »On promatra povijest spasenja ne više kao historičar, kao neki kazališni komad koji se pred njegovim očima odvija. On ju pak promatra kao vjernik, i to ne kao Židov vjernik, nego kao kršćanin vjernik, kako bi živio od toga. Ona je njegova povijest i ne može sebe izuzeti iz nje same. ${ }^{37}$

Ovdje je Origen osobito aktualan jer se upravo ta dimenzija nutrine, obraćenja, zapostavlja u razumijevanju Svetoga pisma. Origen, koji također pristupa Pismu znanstveno, pokazuje svu nedostatnost isključivo znanstvene metode za razumijevanje Pisma. Duhovnost, obraćenje egzegeta teologa nije nijekanje znanstvenoga istraživanje Pisma, nego predstavlja dodatnu, ali time presudnu dimenziju bez koje isključivo znanstveno istraživanje Pisma zapravo prestaje biti znanstveno. Jer smisao znanstvenosti jest što cjelovitije i objektivnije razumijevanje određenoga objekta istraživanja. U tumačenju Pisma upravo duhovno tumačenje, koje se oslanja na nutrinu, obraćenje tumača, jest doprinos znanstvenijem istraživanju Pisma, ako se Pismo tumači istim onim duhom (Kristovim Duhom) na temelju kojega je ono i nastalo. Suprotno današnjemu uobičajenomu shvaćanju među mnogim egzegetima mogli bismo reći da ta dodatna dimenzija (duhovno tumačenje) u znanstvenom istraživanju jest također znanstvena dimenzija jer ona donosi ono što pripada samom tekstu, ono što čini smisao istoga teksta. Ono što Origen traži jest dakle duhovno čitanje, koje ne niječe, dakako, znanstveno istraživanje, ali koje zahtijeva više od toga, a to je duh, duhovnost, nutrinu. U tom se smislu možemo složiti s de Lubacom kada tvrdi da »evanđelje ne može razotkriti cijelo svoje otajstvo običnomu promišljanju kao i neosobnoj znanosti $\ll^{38}$.

To pak ne znači da su sva Origenova tumačenja uvijek ispravna. Često su ona izraz duhovnoga stanja samoga Origena ili pak određenih tema i problema ondašnje Cr-

\footnotetext{
${ }^{36}$ H. de LUBAC, Geist aus der Geschichte, 456s.

${ }^{37}$ Isto, 463. Teza spomenute knjige P. W. Martensa (Origen and Scripture. The Contours of the Exegetical Llife) jest upravo ta da Origen tumači Pismo kao unutar »drame spasenja «, vlastitoga spasenja, kao i spasenja cijeloga svijeta.

${ }^{38}$ Isto, 246.
} 
kve. No i kao takva, u svojoj ograničenosti pokazuju Origenovu predanost Pismu, odnosno kako on svoju nutrinu, osobnost oblikuje i njeguje Svetim pismom. Stoga i Henri de Lubac, koji također upozorava na ograničenost mnogih Origenovih duhovnih interpretacija Pisma, s pravom vrjednuje upravo predano, strastveno traženje duhovnoga smisla u Pismu u Aleksandrinca. ${ }^{39}$

Na koncu treba reći da za Origena »vrelo nutrine « nije jedini uvjet za istinsko duhovno tumačenje Pisma. Naime Origen u mnogim svojim djelima upozorava da treba razlikovati ono što se u Pismu treba shvaćati doslovno od onoga što se treba shvaćati alegorijski. Tako treba ponekad odbacivati slovo koje ubija (2 Kor 3, 6), a ponekad pak braniti doslovnost Pisma, njegovo svojstvo korisnosti i obvezatnosti. ${ }^{40}$ Znati istodobno vaditi iz riznice staro i novo (Mt 13, 52). Koje je pravilo toga razlikovanja? Origen izričito ne spominje pravilo, a ono se podrazumijeva u njegovim spisima, a to su: vjera u Isusa Krista, otvorenost Duhu Svetomu koji je autor Pisma te »pravilo vjere «, odnosno dogme, život Crkve. Osobito je pravilo Crkve ono što čuva egzegeta, teologa, od subjektivizma, a time od pogrješnih i heretičkih tumačenja Pisma: >Ima mnogo ljudi koji drže da misle Kristove misli. Ipak jedni sude drukčije nego drugi. Zato valja čuvati crkveno naviještanje koje su predali apostoli po redu nasljedstva i koje je do danas nazočno u Crkvama. Samo u onu istinu treba vjerovati koja se ničim ne razlikuje od crkvene i apostolske Predaje. ${ }^{41}$

\subsection{Neiscrpanost Pisma}

Za Origena duhovno tumačenje Pisma podrazumijeva da ne postoji jednom zauvijek zadani smisao. Već smo bili naveli misao Grgura Velikoga da »Pismo raste našim čitanjem Pisma «. Pismo zaista »raste « našim čitanjem, odnosno uvijek iznova otkrivamo dublji smisao Pisma jer ne govorimo o bilo kakvoj riječi, nego o Božjoj Riječi koja ostaje trajno vjerniku skrivena, nikad do kraja spoznata. Pismo je poput neiscrpna vrela jer je riječ o vrelu samoga Boga. Origen tu skrivenost i neiscrpnost Pisma pojašnjava i razlikovanjem tijela, duše i duha. Kao što se u čovjeku mogu razlikovati tijelo, duša i duh, tako i u Pismu: slovo, unutarnji smisao unutar samoga slova, ali $\mathrm{i} \gg$ duh $\ll$, odnosno $\gg$ nebeske istine $\ll \cdot{ }^{42} \gg$ Nebeske istine $\ll$ za Origena izri-

\footnotetext{
${ }^{39}$ Isto, 360. Prema Jeanu Daniélou ta se ograničenost očituje ponajprije u prevelikom utjecaju Filonove egzegeze (pretjerano spiritualiziranje, moraliziranje biblijskih tekstova gdje to nije prikladno) i gnostičke egzegeze (biblijski tekstovi slike su skrivenoga, nebeskoga svijeta) koja udaljava Origen u nekim njegovim tumačenjima od uobičajene alegorijske egzegeze Crkve ondašnjega vremena. Usp. J. DANIÉLOU, Origene. Il genio del Cristianesimo, 227-242.

${ }^{40}$ Usp. Hom. Num., 11, 1-2.

${ }^{41}$ Počela, predg. 2.

${ }^{42}$ Usp. Hom. Lev., 5, 1.; Hom. Lev., 5, 5.
} 
ču sam život Boga koji, dakako, nikad do kraja ne može biti razotkriven. Ali to ne samo da ne priječi nego još više izaziva, potiče i ohrabruje vjernika na istraživanje Pisma. Zato stalno treba istraživati Pismo, treba uvijek pjevati, piše Origen, »novu pjesmu «, uvijek iznova promišljati i donositi na svjetlo dana uvijek nova i svježa tumačenja Svetoga pisma. ${ }^{43}$

Aleksandrijski se teolog također pita zašto su određeni tekstovi Pisma zagonetni. Prema njemu, neke je tekstove Bog namjerno učinio zagonetnim. Štoviše, neki su toliko zagonetni da gotovo pružaju mogućnost nevjerovanja u Boga. No Bog dopušta da određeni svetopisamski tekstovi budu zagonetni i nerazumljivi kako bi pokazao da snaga njegove Riječi dolazi od njega samoga, a ne od čovjekove mudrosti. ${ }^{44}$ Zagonetnost, nerazumljivost na taj način izriče uzvišenost, veličinu Božje spoznaje koja nadilazi čovjekovu spoznaju. Tako Bog donosi zagonetne tekstove $\gg$ kako bi onoga koji dublje misli i koji je pozorniji potaknuo da istražuje ponore Pisma te $u$ tome otkrije istinski Boga dostojan smisao $\ll .{ }^{45}$ Posebno je ta misao značajna za Origena. Origen se raduje zbog zagonetnih i teško razumljivih tekstova, ne trudi se na brzinu prodrijeti u njihov smisao ili preko njih pak olako prijeći jer upravo ti tekstovi bude veće i predanije spoznajno traganje za dubokim smislom koji se krije u tim tekstovima. I kada on nudi svoja tumačenja, uvijek to čini sa zadrškom, često se koristi prilogom $\gg$ možda «, pozivajući time na nenametljiv i profinjen način vjernika da se i on sam upusti u to duhovno-spoznajno traganje za značenjem Božje riječi. ${ }^{46}$

Isto je tako Bog namjerno obukao Pismo ovojnicom skrivenosti kako bi svoju riječ očuvao od neznalica ${ }^{47}$, ali kako bi i $\gg$ mudre «, učene potaknuo na istraživanje. ${ }^{48} \mathrm{I}$ samo oni koje se boje Boga, koji su ponizni, dakle koji priznaju svoju ograničenost i uzvišenost Božje Riječi, mogu doći do spoznaje Pisma. (Ps 31, 20) ${ }^{49}$

No vjernik treba biti pozoran i na jasne riječi Pisma jer se također i u njima krije duboko značenje koje nam može promaknuti ako nismo pozorni: »Treba se prema svim riječima ophoditi brižno, također i prema onima koje smatramo jasnima, jer

\footnotetext{
${ }^{43}$ Usp. Die lateinisch erhaltene Homilie über 1 Sam. 1-2, 9.

${ }^{44}$ Počela, 4, 1, 7.

${ }^{45}$ Citat kod: H. de LUBAC, Geist aus der Geschichte, 124.

${ }^{46}$ Više o tome vidi: G. BENDINELLI, Il 'didakalos' origeniano, tra amore delle lettere e ricerca del Logos. Teoria e prassi di un ministero ecclesiale, u: L. F. PIZZOLATO, M. RIZZI (ur.), Origene maestro spirituale, 205-207.

${ }^{47}$ Usp. Hom. Num., 18, 4.

${ }^{48}$ Usp. Contra Celsum, 3, 45.

${ }^{49}$ Usp. Comm. ep. Rom., 2, 8. (Römerbriefkommentar, I-VI, übersetzt und eingeleitet von Th. Heither, Freiburg - Basel - Wien, 1990. - 1999.)
} 
i tada se nadamo da će onaj, koji ispravno traži, također i kod takve riječi, spram koje se ništa ne očekuje i koja se smatra jednostavnom, pronaći nešto što je dostojno Isusovih usta. Ako pak nigdje ne nađemo ništa, tada je to zbog nas samih, a ne zbog Isusove riječi, kao da ona ne nadahnjuje nauke iz Božje punine, nauke pune istine i mudrosti. $\ll{ }^{50}$ Štoviše, upravo $\gg$ siromaštvo slova $\ll$ jest ono što Origena tjera da se traži $\gg$ bogatstvo duhovnoga smisla $\ll^{51}$. Istu misao susrećemo i u njegovoj propovijedi o knjizi proroka Izaije: »Ako katkad ne razumijemo ono što je rečeno, nemojmo zbog toga odustajati i pribjegavati lakšim rješenjima, nego očekujmo da nam Božja milost pruži, prosvjetljenjem spoznaje, tumačenje poteškoća, ili barem da nam Božja milost da svjetlost onako kako ona to hoće, tako da ne moramo još tražiti, nego da se razriješi naša poteškoća; ako nam Bog daruje spoznaju, bit će još očitije da je razlog nerazumijevanja (tame) u nama samima. $\ll^{52}$

Također važnost pozornosti spram svake riječi Svetoga pisma Origen opravdava tumačenjem Kristova preobraženja. Kristovu bijelu odjeću pri preobraženju on naziva »odjećom riječi i slova evanđelja « kojima se Krist zaodjenuo. ${ }^{53}$ Upravo je zbog toga svaka riječ Pisma bitna. ${ }^{54}$

Oba pristupa zagonetnosti, nejasnoći, kao i jasnoći Pisma pokazuju Origenovu poniznost spram velikoga otajstva Svetoga pisma. Koliko Origen poštuje uzvišenost Pisma kao Božje riječi, dokazuje i predivan pojam kojim se koristi, a taj je da Pismu trebamo pristupati »tapkajući.$_{.}^{55}$ Origen često govori o sebi kao »najmanjemu « u tumačenju Pisma (1 Kor 15, 9). ${ }^{56}$ Posebno je dojmljiv tekst iz njegova komentara Pjesmi nad pjesmama gdje opisuje samoga sebe: »Zaručnica zadržava zaručnika; a on odlazi tek što ga je ona vidjela. To on čini često u Pjesmi te to nitko ne može shvatiti ako to sam nije propatio. Bog mi je svjedok da sam često gledao da mi se Zaručnik bliži i da je snažno prisutan sa mnom; a onda se naglo povukao i nisam ga više mogao pronaći, premda sam to htio. Stoga sam čeznuo za njim da ponovno dođe, i ponekad je i došao. A onda opet, kad se pojavio i kad sam ga imao, još

\footnotetext{
${ }^{50}$ Das Evangelium nach Johannes (übersetzt und eingeführt von R. Gögler, Zürich - Köln, 1959.), 20, 36. Također usp. Contra Celsum 6, 2.

${ }^{51}$ Hom. Num., 12, 1.

${ }^{52}$ Hom. Is., 2, 1.

${ }^{53}$ Usp. Der Kommentar zum Evangelium nach Mattäus (Eingeleitet, übersetzt und mit Anmerkungen versehen von H. J. Vogt, Stuttgart, 1983. - 1993.), 12, 38.

${ }^{54}$ Usp. Hom. Jos., 20, 1.

${ }^{55}$ Hom. Jos., 12, 2. (Homélies sur Josué, introduction, traduction et notes de A. Jaubert, Paris, 1960.)

${ }^{56}$ Usp. isto, 23, 4.
} 
jednom mi je izmaknuo; i kad mi je izmaknuo, moje traganje za njim započinje ispočetka. I tako on to čini sa mnom neprestano. ${ }^{57}$

Origen zato ponizno priznaje kako ni njega nije dovoljno zapalio oganj Božje riječi, jer Božja riječ želi biti djelotvorna u njegovu, u našem životu: »I ja također razmatram o Gospodinovim riječima i često ih proučavam. No, nisam siguran jesam li takav da u mojem razmatranju oganj proizlazi iz svake Božje riječi te ražaruje moje srce i zapaljuje moju dušu, da izvršavam ono o čemu razmatram. $\ll^{58}$

Uvijek će Božja riječ ostati tajnovita i propovjednik, egzeget, ako ne može shvatiti riječ, ne treba činiti nasilje riječi ${ }^{59}$, tj. mijenjati istinu kako bi ju sebi prilagodio, nego ju jednostavno ostaviti Gospodinu, odnosno da riječ ostane Gospodinova u svojoj zagonetnosti. $^{60}$

\section{Stari zavjet}

\subsection{GnOZa i StARi ZAVJeT}

Jedan od najvećih izazova za prvu Crkva bila je hereza gnoze. Gnoza je postavila u pitanje cjelokupni kršćanski nauk o Bogu, Isusu Kristu, Crkvi, svijetu te je stvorila veliku zbrku i nered među samim kršćanima. Posebice je to bilo vidljivo u gnostičkom razumijevanju Sv. pisma, osobito Staroga zavjeta i njegova odnosa prema Novom zavjetu. $S$ tim gnostičkim razumijevanjem Pisma morali su se suočavati svi veliki kršćanski mislioci prvih stoljeća, pa tako i sam Origen. Origen nam govori da su gnostičari ${ }^{61}$ pozornim čitanjem Pisma uvidjeli mnogobrojne problematične starozavjetne tekstove, napose one tekstove koji govore o srditom, ljutitom Bogu, o Bogu koji je upleten u ratove, ubojstva. Za njih su ti tekstovi bili u očitom proturječju s Novim zavjetom, s radosnom porukom Isusa Krista o Bogu ljubavi i milosrđa. Zato su gnostičari zaključili da Stari zavjet ne može biti Božja knjiga, knjiga dobroga Boga Isusa Krista, nego knjiga zla Boga. Stoga kršćani ne bi smjeli smatrati Stari zavjet Svetim pismom. Gnostičari su također tvrdili da Isus Krist nema nikakve veze s poviješću izraelskoga naroda, da se treba tumačiti potpuno neovisno o Starom zavjetu. Posljedica takva gnostičkoga pristupa, kojim se ovdje ne možemo baviti, jest da se Stari zavjet u cijelosti odbacivao ili ga se smatralo običnom povi-

\footnotetext{
${ }^{57}$ Commento al Cantico dei cantici 1, 7. (Introduzione, traduzione e note a cura di M. Simonetti, Roma, 2005.)

${ }^{58}$ Hom. in Ps. 38, $1,7$.

${ }^{59}$ Usp. Hom. Lev., 7, 4.

${ }^{60}$ Usp. isto, 5, 3.; 5, 8.

${ }^{61}$ Origen uglavnom misli na Marciona, Valentina i Bazilida. Više o tome: P. W. MARTENS, Origen and Scripture, 114-131.
} 
jesnom knjigom, knjigom koju se eventualno može povijesno istraživati, ali koja ništa ne znači za život vjere. Druga je posljedica, dakako, pogrješno tumačenje Isusa Krista u gnostičara, jer su ga oni tumačili protiv Staroga zavjeta, pa je Isus Krist prestao biti Krist vjere Crkve. K tomu takav Krist bez povijesti spasenja izraelskoga naroda, bez Staroga zavjeta, postao je Krist bez »povijesti «: bez stvarnoga tijela, bez stvarne patnje i smrti.

Hereza gnostičara, odnosno Marcionova hereza, kojoj se ponajviše protivi Origen, a koja se uvijek iznova pojavljuje u Crkvi, ${ }^{62}$ pokazuje što se događa s teologijom, $\mathrm{s}$ tumačenjem Pisma, ako se ono udalji od Staroga zavjeta: nijekanje povijesti spasenja i stvarnoga povijesnoga Isusa, nijekanje Boga koji je postao čovjekom, koji je ušao u povijest, koji je patio i umro. Bog postaje zamišljeni, apstraktni Bog, Bog bez $\gg$ tijela «, bez povijesti i bez stvarnosti. Treba imati također na umu da je Marcion na svojoj strani imao i poganske filozofe koji su se također izrugivali Židovima i kršćanima zbog, za njih primitivnih te Boga i čovjeka nedostojnih, pripovijesti o Bogu koji djeluje u povijesti, Bogu koji je postao čovjekom. Naočigled takve kritike Origen među prvima, a potom i ostali teolozi (na Zapadu posebice Tertulijan) žestoko brane Stari zavjet kao Božju riječ. Štoviše, stvarni autor Staroga zavjeta jest sam Isus Krist te stoga Stari zavjet nije i ne može biti u suprotnosti s njegovom osobom i porukom.

No pritisak na kršćane da odbace Stari zavjet dolazio je na određen način i od samih Židova i od njihova tumačenja Staroga zavjeta. Budući da su židovska tumačenja odbacivala kršćanski pristup Staromu zavjetu, njegovo tumačenje u svjetlu Isusa Krista, moglo se očekivati da će i zbog toga kršćani lako odbaciti Stari zavjet i cijelu povijest spasenja u izraelskom narodu. No to se nije dogodilo. To nam pokazuje koliko su kršćanski teolozi prvih stoljeća, a među njima i Origen, zapravo bili hrabri u svojem ustrajanju obrane Staroga zavjeta, bilo spram poganske, bilo spram židovske kritike Staroga zavjeta.

Tema Staroga zavjeta i danas je vrlo značajna jer se u današnjoj teologiji i duhovnosti može primijetiti slična problematika, slično propitivanje, a potom i relativiziranje, odbacivanje Staroga zavjeta. Naime i danas se u teologiji vode nemale rasprave kako povijesno-kritički razumjeti određene starozavjetne tekstove koji govore o ratovima, nasilju i ubojstvima. Odnosno, i danas se upozorava, kako je isto činio i Marcion, da su ti tekstovi opasni za kršćane jer ih mogu navesti na opravdanje ratova i nasilja itd. Stoga se ti problematični tekstovi jednostavno zaobilaze ili ih

${ }^{62}$ Više o gnostičkom razumijevanju Svetoga pisma, osobito o pojavi gnoze u današnjoj biblijskoj teologiji vidi: L. SCHWIENHORST-SCHÖNBERGER, Povratak Markiona, u: Medunarodni katolički časopis Communio 40(2014.)121, 77-88. Također: I. RAGUŽ, »Deus Caritas est « i gnoza, u: ISTI, Teološki fragmenti I., Đakovo, 2016., 158-169. 
se nastoji isključivo povijesno tumačiti, bez ikakve veze s Novim zavjetom, s Isusom Kristom, odnosno sa životom vjere. Dakle čini se točno onako kako je to činio Marcion: Staromu zavjetu pristupa se kao običnoj povijesnoj knjizi, knjizi koja je još samo korisna za razumijevanje povijesti izraelskoga naroda i drugih okolnih naroda (religija, kultura). Ili se pak Stari zavjet shvaća kao knjigu koju valja jedino još tekstualno-kritički, filološki istraživati, ali ništa više od toga. Stoga Stari zavjet sve više prestaje biti teološka, duhovna knjiga, knjiga važna za kršćanski život vjere, za Crkvu. U tom je smislu danas Stari zavjet zaboravljen u teologiji. Taj se isti zaborav također može primijetiti i u propovijedima i u duhovnim nagovorima, gdje se dobiva dojam da Stari zavjet uopće nije Božja riječ za kršćane jer se rijetko propovijeda polazeći od starozavjetnih tekstova, sve se manje njima koristi u katehezi. Čini se kao da je i danas, unatoč razvoju biblijskih znanosti, Stari zavjet za većinu kršćana zaista $\gg$ stari «, da je prestao nadahnjivati i oblikovati vjerski život većine kršćana.

\subsection{Origen i Stari zavjet}

No vratimo se Origenu. Još jednom treba reći da je zaista čudesno to što u tako kriznoj situaciji, bilo od Marciona, bilo od pogana, bilo od Židova, Origen čvrsto ustraje na obrani Staroga zavjeta, tvrdeći, slijedeći sv. Pavla, da kršćani jesu i uvijek moraju ostati $\gg$ Židovi u nutrini ${ }^{63}(\operatorname{Rim} 2,28-29)$. Kako smo već istaknuli u prvom poglavlju, razlog takvoga pozitivnoga vrjednovanja Staroga zavjeta jest pozorno čitanje Novoga zavjeta, gdje sam Krist u Ivanovu evanđelju kaže da je on prisutan u Starom zavjetu ili pak u Lukinu evanđelju na putu u Emaus govori učenicima što se o njemu govori u Starom zavjetu te naposljetku i sam Pavao i njegovo tumačenje Staroga zavjeta.

Tako za Origena kršćani trebaju biti posvećeni jednako proučavanju Novoga kao i Staroga zavjeta, odnosno $\gg$ znanosti Zakona $\ll{ }^{64}$. Koliko je Origenu Stari zavjet bitan, svjedoči i činjenica da su za njega oba zavjeta uvijek »novi zavjeti, ne zbog vremenskoga datuma, nego zbog novosti smisla $\ll^{65}$. Za Origena ne postoji oprečnost između Staroga i Novoga zavjeta, štoviše, oba su Zavjeta skladno povezana. ${ }^{66}$ Međutim taj se sklad može shvatiti jedino ako se cijelo Pismo promatra u Isusu Kristu. Isus je svojim životom povezao oba Zavjeta, iz obaju napravio je jednu jedincatu harfu i jednu pjesmu: »Prije Kristova dolaska Zakon i Proroci nisu posjedovali

\footnotetext{
${ }^{63}$ Usp. Hom. Jos., 13, 1.; Hom. Lev., 5, 1.

${ }^{64}$ Hom. Num., 7, 2.

${ }^{65}$ Isto, $9,4$.

${ }^{66} \mathrm{U}$ današnjim biblijskim znanostima takav harmonijski pristup Pismu zastupa tzv. kanonska egzegeza. Vidi o tome: I. RAGUŽ, Joseph Ratzinger - Benedikt XVI. o egzegezi, u: ISTI (prir.), Teološka promišljanja o knjizi Isus iz Nazareta Josepha Ratzingera/Benedikta XVI., Zagreb, 2009., 11-19.
} 
navještaj onoga što se očituje jasno u evanđelju, jer Onaj, koji je trebao rasvijetliti njihova otajstva, nije još bio došao. No, kad je Otkupitelj došao k nama i evanđelju podario tijelo, tada je on evanđeljem sve suobličio evanđelju. $\ll^{67}$ (Ivan 1,8$)$ To znači da je za Origena i Stari zavjet u pravom smislu evanđelje, radosna vijest. ${ }^{68}$ Stari zavjet figura je Novoga zavjeta i figura budućnosti: $\gg$ Dakle, traži u svakom znaku Staroga zavjeta figuru onoga što je u Novom zavjetu, a ono što je znak u Novom zavjetu naznaka je onoga što će biti u budućnosti ili pak u sljedećim pokoljenjima, nakon što se znak dogodio. ${ }^{69}$

Dakako, nužno je, prema Origenu, da čovjek živi duhovno, u ljubavi, jer jedino tako može se razumjeti Stari i Novi zavjet, a time i novost evanđelja, inače će oba zavjeta $\gg$ ostarjeti $\ll{ }^{70}$. Cijelo Pismo, Stari i Novi zavjet, za Aleksandrinca nalikuje bademu: prvo susrećemo ljusku, doslovni smisao, potom ovojnicu, moralni smisao, te samu jezgru u kojoj se nalaze otajstva Mudrosti i Božjega znanja. ${ }^{71}$

$\mathrm{Za}$ Origena heretici promašuju Stari zavjet jer ne slijede pravilo vjere ${ }^{72}$, jer bez ikakva razlikovanja upotrebljavaju grčki način mišljenja za tumačenje Pisma. Primjerice u homiliji Knjige Brojeva Origen shvaća Koraha kao onoga koji predstavlja heretike. Kao što je Korah pogrješnom vatrom htio štovati Boga, to isto čine i heretici jer »heretici stavljaju 'stranu vatru', tj. uvodeći značenje i tumačenje koje je strano Bogu i protivno istini. Na taj način oni ne prinose slatki tamjan Bogu, nego onaj koji je prijezira vrijedan $\ll{ }^{73}$ Slično vrijedi i za Židove, koje Origen naziva $\gg$ literaristima $\ll{ }^{74}$ Origen time ne želi reći kako je sva židovska egzegeza doslovna, jer i on sam koristi se alegorijskim tumačenjem Pisma koje se može naći kod Židova. No Židovi »doslovno « tumače Pismo glede Zakona (zapovijedi, obredi) i Proroka, tj. ne uspijevaju uvidjeti duhovno značenje jednoga i drugoga, a koje za

${ }^{67}$ Citat H. de LUBAC, Geist aus der Geschichte, 322s. Također Origenov Der Kommentar zum Evangelium nach Mattäus, 12, 38. Origen tu tumači Kristovo preobraženje kao »preobraženje « Zakona i Proroka, ako onaj tko gleda Isusa u slavi, gleda s njim i Mojsija i Iilju na drukčiji, Kristov način. Augustin će opet kristološko gledanje Staroga zavjeta sažeti na sličan način: »Modo ergo tota intentio nostra est, quando Psalmum audimus, quando Prophetam, quando Legem, quae omnia antequam veniret in carne Dominus noster Iesus Christus, conscripta sunt, Christum ibi videre, Christum ibi intellegere.« (En. in Ps 98, 1)

${ }^{68}$ Usp. Das Evangelium nach Johannes, 1, 33: 4, 11 . 1-7. i 1, 36; 4, 11.18-23. Također 1, 85; 4, 10.10-14.

${ }^{69}$ Der Kommentar zum Evangelium nach Mattäus, 12, 3.

${ }^{70}$ Usp. Hom. Num., 9, 4.

${ }^{71}$ Usp. isto, 9, 7.

${ }^{72}$ Hom. in Ps. 36, 4, 1.

${ }^{73}$ Hom. Num., 9, 1.

${ }^{74}$ Vidi P. W. MARTENS, Origen and Scripture, 133-156. 
Origena, kao i za druge kršćane, proizlazi upravo iz vjere u Isusa Krista. Tako Židovi griješe glede Pisma jer ga ne tumače duhovno, u smislu vjere u Isusa Krista, a heretici (gnostičari) čine isto, tj. ne tumače Pismo duhovno ako isključuju Krista iz Staroga zavjeta. ${ }^{75}$ Ipak, Origen je daleko blaži u svojoj kritici židovskoga pristupa Pismu od pristupa gnostičkih heretika.

Također Origen, kao ni drugi crkveni oci, nema uopće nikakvih poteškoća glede onih tekstova koje su heretici smatrali problematičnima i skandaloznima, a to su starozavjetni tekstovi koji govore o nasilju, ubojstvu, mržnji itd. Zanimljivo je primijetiti da se ista problematika nastavlja i u mnogih današnjih bibličara koji također smatraju takve tekstove problematičnima te ih pokušavaju »opravdati « ponajviše povijesnim kontekstom, a manje alegorijskim tumačenjem. $U$ tom smislu današnji bibličari, teolozi i vjernici mogli bi mnogo naučiti od Origena. Jer Origen sasvim mirno sve te problematične tekstove interpretira u svjetlu Isusa Krista, dakle kao alegorije koje trebaju pomoći čovjeku u njegovu krjeposnom i duhovnom životu. Primjerice kada Pismo govori o nasilju prema određenim osobama, tada te $\gg$ osobe « nisu ljudske osobe, nego određeni grijesi, određene požude ${ }^{76}$. Tako Origen piše o Jošui: $\gg$ Premda je Isus (Jošua) ubio svoje neprijatelje, ali ne zato da nas pouči svireposti, kako to misle heretici, nego da u svojim djelima simbolizira buduća otajstva, kako bi u nama bili pobijeni oni kraljevi koji u nama vladaju kraljevstvom grijeha. ${ }^{77}$

Drugim riječima, kršćani prvih stoljeća uopće nisu imali nekih većih problema sa starozavjetnim tekstovima jer su neprestance Stari zavjet čitali vjerom u Isusa Krista. Stoga smatramo da su u današnjoj teologiji nastali problemi oko takvih tekstova upravo zbog gotovo potpunoga nestanka kristološkoga obzorja u tumačenju Staroga zavjeta. ${ }^{78} \mathrm{Ne}$ želimo reći da se kristološkim tumačenjem mogu razriješiti sva pitanja oko problematičnih tekstova Staroga zavjeta, ali od Origena i današnja teologija može mnogo naučiti, ukoliko on pokazuje da se s kršćanskoga gledišta

\footnotetext{
${ }^{75}$ Usp. Hom. Num., 7, 1.

${ }^{76}$ Usp. Hom. Jos., 8, 7.

${ }^{77}$ Isto, 11, 6; 12, 2.

${ }^{78}$ Primjeri takva krajnje nekristološkoga pokušaja rješavanja problema nasilja u Svetom pismu, da navedemo samo neke, jesu: B. JANOWSKI, Ein Gott, der straft und tötet?: Zwölf Fragen zum Gottesbild des Alten Testaments, Neukirchen-Vlyn, 2013.; D. TOMAŠEVIĆ, Bog nasilja u Starom zavjetu. Rat i ratne ideologije u Starom zavjetu, u: Riječki teološki časopis 25(2017.)2, 297-326. Slična kristološka manjkavost, uobičajena kod današnjih bibličara, vidljiva je također i u članku istoga autora, Darka Tomaševića: Noviji načini tumačenja o »nemilosrdnom « i »militantnom « Bogu u Starom zavjetu. Pokušaji tumačenja u svjetlu Još 6-11, u: Bogoslovska smotra 86(2016.)3, 545-573. Bez kristološkoga obzorja teško takve i slične interpretacije mogu uvjeriti čitatelja, napose ako se postavi pitanje kako uopće razumijevati uporabu tih tekstova u liturgiji.
} 
jedino rješenje može i treba tražiti u Novom zavjetu, u kristološkom iščitavanju Staroga zavjeta.

\section{Sveto pismo i propovijed}

\subsection{EGZEGET I PROPOVJEDNIK}

Origen nije bio egzeget $u$ današnjem znanstvenom smislu riječi, kao profesor Svetoga pisma unutar sveučilišnoga, akademskoga sustava. On je, dakako, bio didaskalos - 'učitelj'79, slijedio je ondašnje znanstvene metode u tumačenju tekstova, metode kojima su se koristili u filozofiji i književnosti. No njegov pristup nikad nije bio samo znanstven, školski, predavački, nego, ako tako smijemo reći, uvijek propovjednički, a to znači ponajprije liturgijski. Drugim riječima, njegove su biblijske interpretacije znanstvene, one su plod golema truda u istraživanju i proučavanju Pisma, ali ta je znanstvenost nošena, vođena i ostvarivala se uvijek molitveno i liturgijski u propovijedanju. Jednom riječju, Origen je bio ono što se danas rijetko susreće, egzeget i propovjednik. Ta je činjenica važna za razumijevanje svih Origenovih biblijskih interpretacija i bez nje se ne može razumjeti njegov znanstveno-teološki opus. To znači da je Origen istraživao Pismo kako bi ono moglo biti propovijedano, kako bi se biblijska poruka mogla i trebala prenijeti vjernicima u propovijedi.

U tom smislu Origen pokazuje svu slabost i ograničenost isključivo znanstvenoga, akademskoga, školskoga pristupa Pismu. Naime riječ je o pristupu Pismu izvan liturgijskoga, molitvenoga konteksta. Pismo se ne istražuje, kako je to slučaj u liturgiji, ponajprije kao »život «, kao živa Božja riječ koja u trenutku liturgijskoga navještaja želi zahvatiti i promijeniti čovjekov život, njegov odnos prema Bogu i prema čovjeku. U akademskom kontekstu pak Pismo se izučava kao »znanje «, kao skup činjenica i podataka o određenim biblijskim tekstovima. To je posve teološki opravdano i važno te to Origen također čini u okvirima ondašnje znanstvenosti. No postoji velika opasnost da Pismo unutar isključivo znanstvenoga, akademskoga pristupa ostane »mrtvo slovo « ili, kako bi rekao Origen, da ta tumačenja budu $\gg$ tjelesna «, ona koja ne pokazuju nikakav interes prema Pismu kao »životu «, kao živoj Riječi koja i danas govori čovjeku. Stoga ono po čemu se Origen razlikuje od većine današnjih ezgegeta jest to što njegovo znanstveno istraživanje Pisma, njegovo $\gg$ znanje $\ll$ o Pismu uvijek proizlazi i usmjereno je prema $\gg$ životu $\ll$ Pisma, prema njegovoj živoj poruci koja zahvaća u život vjernika, zajednice, Crkve. U tom smislu Origen uvijek egzegetira Pismo kao propovjednik i propovijeda kao egzeget.

${ }^{79}$ Više o tome vidi: G. BENDINELLI, Il 'didakalos' origeniano, tra amore delle lettere e ricerca del Logos, 187-209. 
Dakako, kao što smo već istaknuli, nisu sva Origenova historijska i duhovna tumačenja prihvatljiva, mnogobrojna zapravo svjedoče o posebnosti, ograničenosti njegova vremena i njegove osobnosti. No to ne vrijedi samo za Origena, nego za sve teologe, a time osobito za znanstvene interpretacije Pisma. Naime ono što se često zaboravlja u kritici Origenova duhovnoga tumačenja Pisma, koje je umjetno, neznanstveno i neprihvatljivo, jest da se ta ista kritika odnosi i na sam znanstveni pristup Pismu. Pogledamo li biblijske znanosti u posljednjih dvjestotinjak godina, ostat ćemo začuđeni do kakvih su sve interpretacija, često posve oprečnih i proturječnih, dolazili i danas dolaze upravo bibličari koristeći se znanstvenom metodom! Dakle ista problematika, a to je ograničenost kontekstom određenoga vremena, odnosi se bilo na duhovno bilo na znanstveno tumačenje Pisma. Ono pak što Origena čini velikim teologom i egzegetom, osim njegovih genijalnih uvida u Pismo kojima ga on doslovno oživljuje, jest teološko ozračje koje se susreće kod njega. Origen čitatelja (slušatelja) uvodi u ozračje Pisma, uči ga kako čitati, razmatrati, tumačiti, a onda i kako moliti s Pismom. U Origena ne postoji danas tipična shizofrena diskrepancija između egzegeze i homiletike, biblijske znanosti i sustavne teologije, biblijske filologije i teološkoga mišljenja, znanosti i prakse. Možda je upravo u tom jedinstvu jednoga i drugoga njegova najveća zasluga i vjerojatno je također zbog toga imao tako velik utjecaj na svu kasniju teologiju, duhovnost i propovjedništvo.

Pogledajmo sada kako Origen opisuje propovjednika, svećenika, kao osobu Pisma, tj. kako bi se propovjednik trebao ophoditi prema Pismu, ali i prema vjernicima. ${ }^{80}$

\subsection{SVOJSTVA PROPOVJEDNIKA}

Origen je snažan u slikama kojima se koristi kako bi opisao službu propovjednika. Posebice je lijepa misao, koja je zapravo istinski uvjet istinskoga propovjednika, a ona glasi da svaki vjernik, a osobito propovjednik, treba imati unutar svojega srca »biblioteku božanske Riječi ${ }^{81}$. Origen pritom misli na vjeru, nadu i ljubav, a posebice na Sv. pismo. Aleksandrijski teolog time želi reći da svećenik, propovjednik, ako u sebi ne njeguje »biblioteku božanske Riječi«, tada ne govori Božje, već svoje misli. Stoga u našega pisca neprestano susrećemo misao da se Pismo ne treba tumačiti $\gg$ in corde suo «, nego isključivo $\gg$ de sancto Spirito «: $\gg$ Si itaque invenio in Moyse et in prophetis sensum Christi, non de corde proprio, sed de sancto Spiritu loquor. $\ll^{82}$ Ili pak, kako također na drugim mjestima često ponavlja, Pismo se tre-

\footnotetext{
${ }^{80}$ Više o toj temi: A. MONACI CASTAGNO, Origene predicatore e il suo publico, Milano, 1988.

${ }^{81}$ Hom. Gen., 2, 6.

${ }^{82}$ Hom. Ez., 2, 2. (Homélies sur Ezéchiel, introduction, traduction et notes, M. Borret, Paris, 1989.) Hom. Lev., 6, 6.
} 
ba tumačiti načinom $\gg$ dostojnim Boga $\ll(\gg$ digne Deo $\ll) .{ }^{83}$ Zato propovjednici ne smiju donositi kao nauk svoje misli, nego $\gg$ misli Duha Svetoga $\ll^{84}$. Ili još bolje na mjestu gdje opisuje sebe: »Prije nego sam počeo tražiti, povjerovao sam i zato sam našao ono što sam tražio. Nisam ju samo našao, nego sam ju izgovorio i navijestio sam ljudima onu istinu koju sam našao. Nisam postao obijestan zbog svoje mudrosti, nakon što sam pronašao istinu, nisam bio napuhan u svojem znanju, nego sam se još više ponizio. Spoznao sam i shvatio da je Gospodin onaj koji poučava svako znanje. Prorok nastavlja promišljati koliko su puno toga o istini govorili filozofi i ostali barbari, $\mathrm{s}$ koliko su truda mnogo govorili, a opet ništa nisu pronašli, jer nisu vjerovali prije traganja. ${ }^{85}$

Heretici se pak, prema Origenu, prepoznaju po tome što pojedine tekstove izolirano promatraju upravo kako bi mogli razviti isključivo svoj nauk ${ }^{86}$, nauk $\gg$ de corde suo «. Zato za Aleksandrinca razumijevanje Pisma traži »velikodušnost duha i pogleda $\ll$ da bi se moglo razumjeti ono što je »neizrecivo i ono što nadilazi ljudsku narav $\ll{ }^{87}$. Origen je bio svjestan uzvišene otajstvenosti Svetoga pisma, jer se radi o samoj Božjoj riječi, i zato je bio svjestan da često ne može sam protumačiti određene tekstove. $U$ tom smislu svi njegovi napori tumačenja vođeni su poniznim priznanjem nedostatnosti i zazivom Duha Svetoga, »Isusova dolaska $\ll{ }^{88} \mathrm{ili} \gg$ pojave snage Isusa Krista, jer u tome se mogu pronaći mudrost, razum i istina; molim da njegova pojava zasvijetli licu moje duše $\ll{ }^{89}$.

Vratimo se Origenovim opisima svojstava propovjednika. Svećenik, a time i propovjednik, trebao bi se u duhovnom životu i u tumačenju Pisma ponašati poput travara: »Kad neki imaju znanje, tada su oni poput onih koji se bave svijetom biljaka. Oni mogu reći kada je neka biljka korisna za koga, koju biljku treba i kada se koja može staviti na neko mjesto na tijelu i kako se mora pripraviti. Upravo je na taj način sveti čovjek neka vrsta travara u duhovnom smislu: on iščitava iz svetih pisama svaku jotu i svako slučajno slovo. Pronalazi snagu slova, zna kakvu korist ono ima i da ništa nije suvišno u pismima. Želiš li čuti i drugu prispodobu: Bog, stvaratelj, stvorio je svaki ud našega tijela za određenu djelatnost. No, nije svatko u stanju znati u čemu se sastoje snaga i korist svakoga pojedinog udana, sve do onoga

\footnotetext{
${ }^{83}$ Hom. Lev., 5, 1.

${ }^{84}$ Comm. ep. Rom., 3, 2.

${ }^{85}$ Isto, 2, 14.

${ }^{86}$ Usp. isto, 3, 7.

${ }^{87}$ Das Evangelium nach Johannes, übersetzt und eingeführt von R. Gögler, Einsiedeln - Köln, 1957., 6, 54.

${ }^{88}$ Die griechisch erhaltenen Jeremiashomilien, 19, 15.

${ }^{89}$ Isto, 19, 11.
} 
najneznatnijeg. To poznaju samo oni koji se, među liječnicima, razumiju u anatomiju, koji znaju reći za čega je stvoren svaki pojedini dio, pa i onaj najmanji. Shvati na taj način također i pisma kao biljke ili kao jedno jedincato dovršeno tijelo. Ako nisi ni travar pisama, ni poznavatelj anatomije proročkih govora, nemoj pomisliti da je nešto u pismima suvišno. Ako ne možeš pronaći smisao svetih pisama, prije sebe optuži, negoli pisma. $\ll^{90}$

Propovjednik treba nalikovati liječniku koji se služi Pismom, Božjim riječima, »lijekovima «, kako bi izliječio bolesti duše vjernika. ${ }^{91}$ Ili je pak propovjednik sijač, sijač Božjih riječi. On treba sijati sjemenke Božje riječi svojim predanim propovijedanjem, njime stvarati $\gg$ svoje potomstvo «, a to je potomstvo Krista koji se u vjernicima oblikuje. ${ }^{92}$ Origen se prema svojim vjernicima nikad ne ophodi paternalistički. Za njega vjernici nikad nisu i ne smiju biti puki slušatelji, nego uvijek sudionici samoga tumačenja i slušanja Božje riječi. To je vidljivo po tome što Origen uvijek iznova moli svoje vjernike da mole za njega. ${ }^{93}$

Svećenik propovjednik također treba biti $\gg$ filomathos $\ll{ }^{94}$, onaj koji je otvoren za stalno učenje u istraživanju Pisma. Time se također zahtijeva od propovjednika velika pozornost u čitanju biblijskih tekstova ${ }^{95}$, koja podrazumijeva velik trud i napor istraživanja i razmatranja nad istim tekstovima. ${ }^{96}$

Nadalje su svećenici pozvani biti ribari ljudi, a njihove mreže trebaju biti načinjene od Svetoga pisma, tako da se pletivo Božje riječi može bacati oko srca slušatelja. ${ }^{97}$ No i sam propovjednik mora se dati uhvatiti mrežom Božje riječi. Što se više mreža Božje riječi zapliće oko propovjednika, oko njegova duhovnoga života, tim će više on biti posvećen Božjoj riječi. ${ }^{98}$ Origen također uspoređuje propovjednika s Kristom koji lomi kruh i hrani gladne. I svećenik propovjednik, da bi nahranio one koji su gladni Božje riječi, mora lomiti Božju riječ, mora ju tumačiti vjernicima. I kao što je za Krista bilo dovoljno malo kruhova i ribica, tako je i za propovjednika dovoljno malo riječi iz Pisma da njima nahrani mnoštvo vjernika. Origen u tom kontekstu upozorava propovjednike da ako te iste Božji riječi ne proučavaju, svaku uzimajući

\footnotetext{
${ }_{90}$ Die griechisch erhaltenen Jeremiashomilien. Fragmente aus der Philokalie, Fr. 39, 2.

${ }^{91}$ Usp. Hom. Ps. 37, 1, 1.

${ }^{92}$ Hom. Ps. 36, 4, 3.

${ }^{93}$ Usp. isto, 4, 4.; Hom. Gen., 3, 5, 9, 1; Hom. Ex., 9, 2; Hom. Lev., 5, 2.

${ }^{94}$ Usp. P. W. MARTENS, Origen and Scripture, 169.

${ }^{95}$ Hom. Ex., 13, 3.

${ }^{96}$ Usp. Comm. ep. Rom., 9, 1, 12.

${ }^{97}$ Usp. Die griechisch erhaltenen Jeremiashomilien, 16, 1.

${ }^{98}$ Usp. Der Kommentar zum Evangelium nach Mattäus, 10, 12.
} 
ozbiljno i pozorno, kao što su učenici dijelili kruh po kruh, oni ne će moći nahraniti vjernike Božjim riječima, ne će im moći pružiti smisao Božjih riječi. ${ }^{99}$ Glede Pisma kao hrane Aleksandrinac piše da što propovjednici više uzimaju hranu Pisma, Božje Riječi, tim će se više ona umnažati, postat će plodna za vjernike, za Crkvu. ${ }^{100}$ Propovjednik je također neka vrsta medara, onoga koji zna izvlačiti iz »košnice « Svetoga pisma med Božjih poruka. ${ }^{101}$

Origen je svjestan da njegovo tumačenje Pisma, njegovo propovijedanje, nije lagano, da ono ima okus gorak i opor, što je slučaj i kod svih proroka, i kod Pavla, i kod Isusa. No jedino po vjerničkoj molitvi njegove propovijedi mogu i trebaju postati »lijek spasenja, jer su neki lijekovi slatki, neki pak opori, a ponekad čak i gorki. Ipak, ako ga se u pravoj mjeri i u pravom trenutku uzima, svaki lijek na svojem mjestu doprinosi ozdravljenju $\ll{ }^{102} \mathrm{U}$ tom smislu Origen propovjednike naziva »Božjim strjelicama«, ako zabadaju Božje riječi u srca vjernika, pozivajući ih na obraćenje. ${ }^{103}$ Takav »gorki i opori« pristup Pismu vrijedi i za samoga propovjednika jer i on uvijek treba propovijedati protiv samoga sebe, odnosno samo Pismo zahtijeva od propovjednika da ono »gori« (Lk 24, 32) u njima, da spaljuje i »čisti « svojom prisutnošću propovjednikove »usne $\ll($ Iz 6,7$)$ kako bi se Božja riječ mogla razumjeti i prihvatiti. ${ }^{104}$

Za našega autora sva pogrješna tumačenja Pisma u svojoj su biti nijekanje mučeništva jer Kristova istina donosi Božju istinu koja nije istina ovoga svijeta te ona kao takva uvijek izaziva mržnju, a time uzrokuje progonstvo, a onda i mučeništvo. ${ }^{105}$ Heretici su pak, govori nam Origen, smatrali da mučeništvo zapravo sprječava ljude da postanu vjernicima jer je tobože mučeništvo kršćana pokazivalo ludilo, nera-

\footnotetext{
${ }^{99}$ Usp. Hom. Gen., 12, 5.

${ }^{100}$ Usp. Hom. Num., 11, 6.

${ }^{101}$ Hom. Is., 2, 2. Augustin se kasnije koristi sličnom poredbom: »Ergo Eucharistia panis noster quotidianus est: sed sic accipiamus illum, ut non solum ventre, sed et mente reficiamur. Virtus enim ipsa quae ibi intellegitur, unitas est, ut redacti in corpus eius, effecti membra eius, simus quod accipimus. Tunc erit vere panis noster quotidianus. Et quod vobis tracto, panis quotidianus est: et quod in Ecclesia lectiones quotidie auditis, panis quotidianus est: et quod hymnos auditis et dicitis, panis quotidianus est. Haec enim sunt necessaria peregrinationi nostrae. Numquid illuc quando venerimus, codicem sumus audituri? Ipsum Verbum visuri, ipsum Verbum audituri, ipsum manducaturi, ipsum bibituri, quomodo Angeli modo.« (Sermo 57, 7, 7)

${ }^{102}$ Die lateinisch erhaltene Homilie über 1 Sam. 1-2, 1.

${ }^{103}$ Usp. Hom. Ps. 36, 3, 3; Hom. Ps. 37, 1, 2; Hom. Ps. 38, $1,7$.

${ }^{104}$ Usp. Hom. Is., 4, 6.

${ }^{105}$ Usp. Hom. Ez., 3, 4-5. Origen ne propušta istaknuti da je dobar, moralan način življenja mnogih heretika način kako da privuku svoje slušatelje, premda sve pogrješno govore. Zato su za Origena takvi heretici daleko štetniji. Usp. isto, 7, 3. Također Hom. Jos., 15, 1.
} 
zumnost same vjere: nepotrebno izlaganje opasnostima, izazivanje rimskih vlasti, odbacivanje ovozemaljskoga života itd. Za Origena, kao i za druge kršćanske pisce prvih stoljeća, mučeništvo je vjerodostojni znak kršćanske vjere, ali i znak istinskoga tumačenja Svetoga pisma. Origen piše: »Baš zato što ne obećava ništa udobno, ništa lagodno, ništa mekušasto, religija treba ulijevati veće pouzdanje. $\ll{ }^{106}$

Nadalje, za aleksandrijskoga teologa, Duh Sveti, koji omogućuje jedino ispravno tumačenje Pisma, nije nekakav apstraktan Duh, nego uvijek samo Duh Crkve kao Kristova Tijela. Onaj koji tumači Pismo može ga ispravno tumačiti samo ako je i sam čovjek Crkve, ako u cijelosti živi u Crkvi i za Crkvu. Origen takvoga teologa, propovjednika, naziva $\gg$ drugim Ivanom $\ll$ : $\gg$ Može se nedvojbeno reći da su evanđelja prvijenci Pisma, a prvijenac je Ivanovo evanđelje, čiji smisao nitko ne može shvatiti ako ne počiva na Isusovim grudima i ako nije uzeo od njega Mariju koja je postala i njegovom majkom. Mora postati takva duhovna veličina da bude tako reći drugi Ivan te da poput Ivana ukazuje kao Isus na Isusa. $\ll{ }^{107}$ Origen misli na scenu iz Ivanova evanđelja u kojoj Isus daruje Ivana Mariji kao »njezina Sina (Iv 19, 26). To znači da je sada za Mariju Ivan novi Isus, a i kršćanin da bi razumio Pismo treba postati Marijin Sin, novi Isus, odnosno da ne živi više on, nego Isus u njemu (Gal 2, 20). Ako se to ne dogodi, propovjednik će zrcaliti samoga sebe.

Naš pisac upotrebljava još jednu lijepu sliku kako bi opisao teologa, propovjedni$\mathrm{ka}$, a to je »šatoraš«. Origen svoju misao shvaća kao šator, kako bi trebao i svaki teolog, propovjednik, prema njemu, svoju misao shvaćati kao šator, kao šator koji treba uvijek iznova pokupiti i nastaviti dalje. Dakle, čim se na jedan način spozna otajstvo, treba težiti uvijek dubljoj i većoj spoznaji, stalno treba pred otajstvima razvijati šator spoznaje, ali ga istodobno uvijek u svojoj ograničenosti i skupljati te uvijek iznova traži nove spoznaje. Tako za Origena teolog, propovjednik, napreduje u duhovnom, intelektualnom životu kao »nomad sa svojim šatorom «: »Duši koja je zapaljena plamenom znanja nikad se ne može dogoditi da počiva, nego ju dobra tjeraju prema boljima, a od boljih do najboljih. ${ }^{108}$

Istinitost se propovjednika naposljetku pokazuje i u tome što on svojim tumačenjem Pisma služi vjernicima. On, tvrdi Origen, poput Krista nalijeva $\gg$ vodu $\ll \mathbf{u} \gg$ posudu $\ll$ duša vjernika kako bi ih oprao ne svojim riječima, nego Božjim riječima. ${ }^{109}$ To se, dakako, ne će dogoditi ako propovjednikova misao bude »besplodna «, ako uvijek donosi samo »stare riječi $\ll$, tj. uvijek iste. A istinski pak propovjednici trebaju otkrivati

\footnotetext{
${ }^{106}$ Comm. Ep. Rom, 2, 13.

${ }^{107}$ Das Evangelium nach Johannes, 1, 4.

${ }^{108}$ Hom. Num., 17, 4.

${ }^{109}$ Usp. Hom. Is., 6, 3.
} 
uvijek $\gg$ novi $\ll$ smisao Pisma, donositi $\gg$ nove $\ll, ~ \gg$ duhovne riječi $\ll$. Jer $\gg$ kruh riječi $\ll$ u propovjednika uvijek treba biti svjež kruh (usp. Lev 9, 3). ${ }^{110}$

Mogli bismo reći da za Origena propovjednik treba biti osoba ushićena, zanesena Pismom jer samo Pismo donosi »ushićenost «: $\gg$ Tko pozorno i s pomnjom izučava proročke knjige, na osnovu samoga čitanja osjetit će mlaz ushićenosti. Taj će ga osjećaj uvjeriti da knjige, za koje mi vjerujemo da su božanske riječi, nisu ljudska djela. ${ }^{111}$ Po Pismu propovjednik, a onda i svaki vjernik već sada postaje pripremljen za vječnost, postaje eshatološka osoba. Naime za Origena Pismo priprema vjernike za ono što će se događati u vječnosti, a to je da ćemo ponovno biti u školi Pisma, ovaj put u školi samoga Isusa Krista. Onaj koji to sada čini bolje se priprema za eshaton. ${ }^{12}$

\subsection{OPASNOSTI PROPOVJEDNIKA}

Origen nije elitist, svjestan je da nisu svi sposobni ući u svojem razmatranju i tumačenju Pisma u dublji, puniji smisao. Ali svi su pozvani istraživati Pismo, svejedno hoće li netko ući bolje u njegove dubine ili pak ostati na površini. Bitno je da je Pismo korisno i za onoga koji je manje savršen kao i za onoga koji je više savršen,

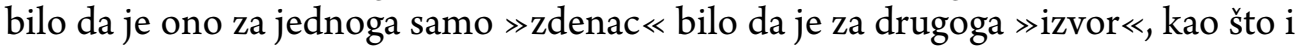
sv. Ivan spominje kod Samarijanke i Isusa i zdenac i izvor. ${ }^{113}$

Origen je svjestan opasnosti ohologa pristupa Pismu u propovjednika. Upozorava na oholost učenih teologa, propovjednika, gdje učeni zbog umišljenosti da bolje tumače Pismo mogu postati oholi ako sebe smatraju mudrijima, a time i savršenijima. ${ }^{114} \mathrm{U}$ tom kontekstu zanimljiva je Origenova primjedba da se za propovjednike opasnost ne krije samo u tome što se možda pretjerano bave ovim svijetom, nego ona može biti u samoj činjenici bavljenja Pismom. Naime postoji, kako naš pisac piše, opasnost u bavljenju »velikim « jer propovjednici nisu u stanju to »veliko podnositi $\ll .{ }^{115} \gg$ Nepodnošenje velikoga $\ll$, a time i Pisma, značilo bi da propovjednici nisu spremni prihvatiti »veličinu « poruke Pisma, posebice tamo gdje ta ista poruka postavlja u pitanje čovjekove uobičajene spoznaje, pa ju onda razvodnjavaju na površna i jeftina tumačenja. Zato Origen zahtijeva od propovjednika sveti strah spram »velikoga « Pisma i u Pismu, dakle ne samo strah spram onoga što je

\footnotetext{
${ }^{110}$ Usp. Hom. Lev., 5, 8.

${ }^{111}$ Počela, 4, 1, 6.

${ }^{112}$ Usp. isto, 2, 11, 5-7.; Više o tome: P. W. MARTENS, Origen and Scripture, 234-242.

${ }^{113}$ Usp. Die griechisch erhaltenen Jeremiashomilien, 18, 4.

${ }^{114}$ Usp. Comm. ep. Rom., 9, 36, 40.

${ }^{115}$ Usp. Hom. Ez., 9, 5.
} 
u svijetu i što bi moglo ugroziti vjeru nego i strah spram »velikoga «, uzvišenoga u Pismu, vjeri i nauku Crkve.

Zato Origen s pravom upozorava kako je jako opasno i kada govorimo istinito o Bogu, o čemu se danas rijetko govori u Crkvi. Naime Origen tvrdi da se opasnost može kriti u pogrješnom tumačenju, predstavljanju toga istinitoga. ${ }^{116}$ To se odnosi na one propovjednike koji, doduše, istinito propovijedaju, donose pravi smisao Pisma, ali ga ne donose u duhu toga istoga Pisma, odnosno sebe stavljaju u središte, na pameti im je kako će sebe time predstaviti. Na taj način takvo propovijedanje, premda istinito, ne donosi nikakva ploda u vjernicima jer ne dolazi iz poniznoga služenja Riječi, nego iz samohvale. Zato je za propovjednika, tvrdi Aleksandrinac, važno ne samo da istinito propovijeda nego da sebe ponizno stavi po strani jer će tako omogućiti Bogu da djeluje u vjernicima, odnosno njegov će govor tada biti prožet »Božjom snagom « $(1$ Kor 2,5$)$ i »ljupkošću « koju Bog daje. ${ }^{117}$

No postoji i oholost $\gg$ jednostavnih $\ll$. Origen je dobro uočio da postoje kršćani koji preziru učene, koji se osjećaju ugroženi učenima jer učeni posjeduju znanje koje oni nemaju. Kritika koju pak ti, tzv. jednostavni kršćani upućuju učenima, tvrdi naš pisac, ne dolazi iz poniznosti, nego iz zavisti i oholosti: svoju neobrazovanost, intelektualnu i duhovnu lijenost i površnost oni skrivaju i pravdaju svojom jednostavnošću, a i učene diskreditiraju te njihov govor nazivaju »brbljavošću $<.{ }^{118}$ Umjesto da im promišljanje učenih bude poticaj da se predanije posvete istraživanju Svetoga pisma, oni kritiziraju učene kako bi ustrajali u svojoj duhovnoj i intelektualnoj tromosti.

Imajući u vidu obje opasnosti, Origen je bio svjestan da je danas malo onih koji istinski propovijedaju, ali i to malo ugroženo je u Crkvi, kako otužno piše Origen i kao da opisuje u mnogočemu i stanje današnje Crkve: »Malo je takvih ljudi, a ako postoji i malo takvih, ni njih i takvih malo nema zbog zavisti i ljubomore, te oni ne mogu koristiti drugima. ${ }^{119} \mathrm{Kad}$ smo se već dotaknuli te teme, Origen je $\mathrm{u}$ vlastitom životu iskusio bolnu činjenicu da istinski propovjednik u svojem navještaju Božje riječi, a time i u tumačenju Sv. pisma, nailazi na poteškoće posvuda: $\gg$ Progonstvo ovoga svijeta, ako govori istinu, a uvrjedu Boga ako zbog straha od ljudi naviješta lažno, umjesto istinitoga. $\ll{ }^{120} U$ homilijama o knjizi proroka Jeremije na mnogim mjestima možemo osjetiti kako Origen opisuje sebe kao propovjedni-

\footnotetext{
${ }^{116}$ Usp. Hom. Ez., 1, 11.

${ }^{117}$ Contra Celsum, 6, 2. Više o tome vidi: I. RAGUŽ, O kršćanskoj retorici ili o raspetom Retoru, u: Međunarodni katolički časopis Communio 43(2017.)130, 100-111.

${ }^{118}$ Usp. Hom. Ps. 36, 5, 1

${ }^{119}$ Isto, 3, 3.

${ }^{120}$ Hom. Ez., 6, 2.
} 
ka, kako se poistovjećuje s prorokom Jeremijom. I on se sam, poput Jeremije, pita zašto se ne bi povukao u samoću i miran život jer mu propovijedanje donosi samo nevolju, muku, bol i mržnju. ${ }^{121}$

Ipak, propovjednik i tada ne smije odustajati. S obzirom na određene zahtjevne biblijske tekstove propovjednik se čak mora i radovati kada druge ražalosti svojim propovijedanjem, kada želi potaknuti grješnike na obraćenje (usp. 2 Kor 2, 2$)^{122}$. Jer Božja Riječ nije igračka, ona je u Božjim rukama, a time i u navještaju propovjednika $\gg$ oružje « u borbi protiv neprijateljskih sila. ${ }^{123}$ Pismo je poput trublje koja vjernike drži budnima, spremnima stalno za bitku. ${ }^{124}$ Aleksandrijski biskup tvrdi da nije dobro pogrješno propovijedati, ali nije dobro ni šutjeti, kao što to čini Pinhas, Elijev sin, jer pate zbog neznanja ili pak zbog grijeha imaju nečistu savjest. Zato je važno raditi na obrazovanju jer olako svećenici mogu postati »Pinhasi «, »zatvorena usta $\ll{ }^{125}$.

Origen je također žestok kritičar crkvene hijerarhije, osobito pod vidom njezine nebrige za Božju riječ, lošega propovijedanja i nerazumijevanja Pisma. Neprestance upozorava kako vjernici, a onda i svećenici, mogu zbog svoje nebrige ostati žedni, premda se nalaze tako blizu izvora Sv. pisma. ${ }^{126}$ Oslanjajući se na $1 \mathrm{Pt} 2$, 9 i Mt 5, 19, Origen tvrdi da su u Crkvi »kraljevi« ponajprije oni što upravljaju Crkvom (biskupi, svećenici), ali za njega su ipak daleko više $\gg$ kraljevi « oni koji »svojim riječima i spisima upravljaju upraviteljima Crkve $\ll{ }^{127}$. Tumači Pisma istinski su kraljevi i knezovi jer su oni $\gg$ kopači « Pisma. Oni koji kopaju po površini slova i dolaze do duhovnoga smisla Pisma. ${ }^{128}$ Zato su propovjednici odgovorni ne samo za sebe nego i za grijehe drugih, posebice za one grijehe koji su učinjeni zbog pogrješna i

${ }^{121}$ Usp. Die griechisch erhaltenen Jeremiashomilien, 20, 8. Vidi o toj temi: V. PERI, Geremia secondo Origene. Esegesi e psicologia della testimonianza profetica, u: Aevum 68(1974.), 1-57.

${ }^{122}$ Usp. Die griechisch erhaltenen Jeremiashomilien, 20, 6.

${ }^{123}$ Usp. H. de LUBAC, Geist aus der Geschichte, 441.

${ }^{124}$ Usp. Hom. Jos., $1,7$.

${ }^{125}$ Usp. Die lateinisch erhaltene Homilie über 1 Sam. 1-2, 7.

${ }^{126}$ Usp. Hom. Gen., 11, 3.

${ }^{127}$ Hom. Num., 12, 2.

${ }^{128}$ Usp. isto, 12, 2. Također Hom. Iud., 4, 2 (Homélies sur les Juges, Introduction, traduction, nots et index par P. Messié, L. Neyrand, M. Borret, Paris, 1993.). Oslanjajući se na tekst iz Suci 3, 31, gdje se spominje kako je Šamgar pobio Filistejce štapom, »ostanom volujskim «, Origen tvrdi da bi tako i propovjednici trebali djelovati ne samo »mačem « (kritikom, argumentima, što je, dakako, važno, propovjednik kao »mač od kamena « koji reže srca vjernika »kamenom «; Isusom Kristom: Hom. Jos., 26, 2) nego i »štapom «, blagim savjetima »kopati« zemlju svojih slušatelja kako bi primili Božju riječ. Evo korisne simbolike za razumijevanje biskupskoga štapa! 
loša navještaja Božje riječi u propovjednika. ${ }^{129}$ Zato Origen upozorava propovjednike da budu vjerni svojemu poslanju da zbog nebrige ne dožive sudbinu sličnu onoj Kornelija iz Djela apostolskih $(8,13-19)$. Origen je svjestan da se to može zaista dogoditi te ponizno priznaje da se to može i njemu dogoditi te govori o toj temi, zapravo, radi svoje $\gg$ osobne obnove $\ll{ }^{130}$. Da se to ne zbude, propovjednik treba tako propovijedati da vjernici postanu $\gg$ ljubomorno pohlepni za spoznajom otajstava ${ }^{131}$.

Jedna od najvećih opasnosti u propovjednika jest ta da propovijedaju kako bi se svidjeli svojim vjernicima. Origen tvrdi da takvi propovjednici imaju $\gg$ ženskaste duše $\ll$ (»effeminatae animae «). To su oni propovjednici koji propovijedaju samo kako bi se svidjeli vjernicima. ${ }^{132}$ Oslanjajući se na starozavjetni zakon da se pashalno janje ne smije jesti sirovo, nego jedino pečeno, Origen piše: »Tko pak priprema sirovo Pismo za kuhanje, taj se mora pobrinuti da napisano ne pretvori u nešto mlohavo, razvodnjeno, raspadnuto, kao što čine oni koji 'gode ušima i odvraćaju od istine' (2 Tim 4, 3-4) te svoja spekulativna tumačenja tekstova usmjeravaju na neodrživ i potpuno razvodnjen način života. Mi ćemo zato žarkim Duhom i ognjenim riječima, koje nam je Bog dao (...), ispeći meso Jaganjca, tako da oni koji ga prime mogu reći: 'Nije li gorjelo srce u nama dok nam je putem govorio, dok nam je otkrivao Pisma?' (Lk 24, 32) ${ }^{133}$

Dakako, nastavlja Origen, potrebno je da propovjednik ostvaruje Božju riječ u svojem životu ${ }^{134}$, da vlastito tijelo ispeče $u$ vatri, pritom navodeći proroka Jeremiju: »Al' tad mi u srcu bî kao rasplamtjeli oganj, zapretan u kostima mojim: uzalud se trudih da izdržim, ne mogoh više.« (Jer 20,9) Ili pak, kako naš pisac primjećuje na drugom mjestu, nije dostatno za propovjednike samo »preživati« Božju riječ, potrebno je imati $\mathrm{i} \gg$ razdvojene papke « (usp. Lev 11,3), odnosno u svojem životu vlastitim djelima »razdvajati ono što je Božje, a što je od svijeta. Dakako, vrijedi i obratno, nije dostatno ni imati »razdvojene papke«, živjeti krjeposno, kako to često čine heretici, što je Origen dobro uvidio, ali ne naučavaju Kristov, nego svoj nauk. $^{135}$

\footnotetext{
${ }^{129}$ Hom. Num., 20, 4.

${ }^{130}$ Isto, 3,1 .

${ }^{131}$ Isto, 22, 2.

${ }^{132}$ Usp. Hom. Ez., 3, 3.

${ }^{133}$ Das Evangelium nach Johannes, 10, 18.

${ }^{134}$ Usp. Hom. Lev., 6, 6.

${ }^{135}$ Usp. isto, 7, 6
} 
Naposljetku, kao veliko upozorenje i današnjoj Crkvi, Origen piše da se zbog nebrige propovjednika može dogoditi da Bog dopusti da u Crkvi nastane velika $\gg$ glad za slušanjem Riječi « jer Božje Riječi više nema u Crvki, nema više propovjednika, osoba po kojima ona može odjekivati (usp. Am 8, 11-12). Štoviše, tvrdi aleksandrijski teolog, Bog može čak zabraniti i prorocima da kao $\gg$ oblaci « prestanu $\gg$ dažditi « Božju riječ $(I z 5,6) .{ }^{136}$ Origen priznaje da se ta glad zaista može dogoditi, ali tada je bitno ostati vjeran Božjoj riječi te o njoj »razmatrati dan i noć« (Ps 1, 2) ${ }^{137}$.

\footnotetext{
${ }^{136}$ Usp. Hom. Ps. 36, 3, 10.

${ }^{137}$ Usp. isto.
} 


\title{
ON SACRED SCRIPTURE IN ORIGEN'S THOUGHT
}

\author{
Ivica RAGUŽ*
}

Summary: The article analyzes Origen's understanding of Scripture. The first part analyzes the conditions and assumptions for understanding Scripture in Origen's thought. St. Paul and his interpretation of the Old Testament play a major role. It also points to the personal life of a believer (spirituality, conversion), which is also one of the basic conditions for a more complete interpretation of Scripture. The second part of the article reflects on Origen's treatment of the Old Testament, especially in the context of the heresy of gnosis. The third part presents Origen as an exegete and a preacher. Origen's exegesis was always motivated and directed at the proclamation of God's word in the liturgy. The advantages of such exegesis and the limitations of purely scientific, academic exegesis are also discussed, as well as his, to the Church still current, reflections on some properties and dangers of the preacher.

Keywords: Origen, Sacred Scripture, Old Testament, exegesis, gnosis, preacher, homily.

\footnotetext{
* Full Prof. Ivica Raguž, Ph. D., Catholic Faculty of Theology in Đakovo, J. J. Strossmayer University of Osijek, P. Preradovića St 17, P. O. box 54, 31400 Đakovo, Croatia, ivica.raguz@os.t-com.hr
} 